\title{
NACSIS-CATを利用したオンライン目録作業 一機械化へのワン・ステップとしてー
}

\author{
Cataloging through the NACSIS-CAT : in the \\ Medical Library \& Information Center, Keio \\ University : One Step toward Total Computerization
}

\author{
永 崎 由紀子*
}

慶応義塾大学医学情報センター

\begin{abstract}
Nagasaki Y. : Cataloging through the NACSIS-CAT in the Medical Library \& Information Center, Keio University : One Step toward Total Computerization. Igaku Toshokan 1991 ; 38 (2) : 105-112.

The Medical Library \& Information Center, Keio University connected up to the NACSIS (National Center for Science Information System) and started to register its currenting held books with the cataloging system the NACSIS-CAT in 1989. We use downloaded records only to make cards now, but we are preparing a total library system for the information centers in Keio University in conjunction with the NACSIS-CAT. This paper reports on how we can use the NACSIS-CAT in cataloging works in the process of becoming total computerization.
\end{abstract}

\section{I .はじめに}

学術情報センター目録システム（以下NACSISCAT）との接続事例はこれまで数多く報告され ている。しかし，医学図書館として単独の報告は ないようである。また，最近の例はすでに全業務 を機械化した図書館のものが多い。慶應義塾大学 医学情報センターでは1989年 6 月接続以来, 徐々 にNACSIS-CATを業務に取入れ，ようやく第一段 階が軌道に乗ったところである。現在は第 2 段階, NACSIS-CATとの連動をふまえた学内 5 センター 共同の全業務機械化に向けて準備に奔走している。 接続館としては比較的新参者であるが，実務上の 変化を中心に, 初期段階の医学図書館の一例とし

\footnotetext{
"Yukiko NAGASAKI : Medical Library \& Information

Center, Keio University, 35 Shinano-machi, Shinjuku-ku, Tokyo 160, Japan.
}

（1991年3月19日＼cjkstart受理）
て, 当センターの経験を問題点も含めてご紹介す る。今後接続を考えている図書館に判断材料を提 供できればと思う。

\section{II . 接続方法}

当センターと学術情報センターとの接続は図 1 のとおりである。まず，学術情報センターと慶 應義塾の本拠地である三田キャンパスにある大 型計算機を専用回線で結んでいる。学内に $5 つ$ ある情報センターの内 4 センターがここを通して NACSIS-CATを利用している。学術情報センター との接続は他にパケット網利用が可能であるが, 対経費の計算で選択することになる。三田キャン パスから医学部のある四谷キャンパスはバスで20 分ほどの距離なのだが, 残念ながら計算機のネッ トワークとしては遠い。多摩川を隔てた神奈川県 横浜市港北区にある日吉キャンパスを経て来ざる を得ない。計算機はすべて共用機で, 計算センター 


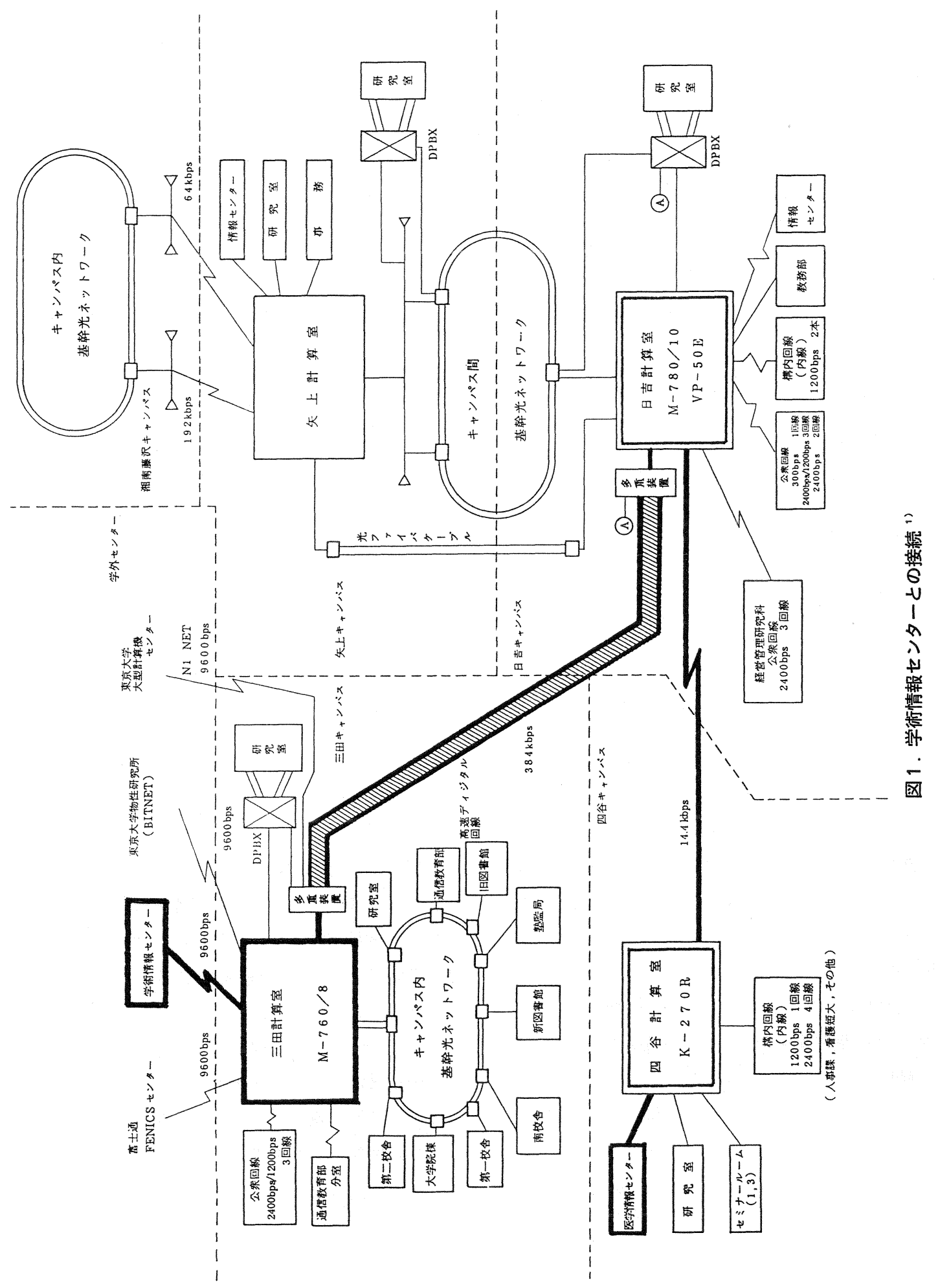


という別組織が管理している。三田の計算機では 登録したレコードをダウンロードしているが他は 単に中継点に過ぎない。

この接続方法で不便なのは, 計算機が共用で, 図書館がメインテナンスをする必要はないものの 他の部署の都合で使えない期間があることである。 2 月の入試時期に機密保持の問題から他業務は一 切拒否されてしまう。また中継点が多いため，そ れぞれの定期メインテナンス, 夏季休暇などの度 に使えないことになる。レスポンスタイムが遅い の屯，道のりが長いためと思われる。

ハード面の事情は個々の図書館によって異なる。 また図書館サイドだけではいかんとすしがたいす のもあるが, 選択の余地があるのなら慎重な検討 が必要となろう。

\section{III. 目録作業}

当センターでは現在端末 1 台, 図書目録担当者 2 名で年間約 3,000 冊受け入れる図書を原則とし て全件登録している。例外は非図書資料, 内部資 料の類のみである, 他に, 雑誌の担当者む学術雑 誌総合目録データのオンライン更新, 新規登録を 同じ端末で行っている。現在のところローカルシ ステムは稼働しておらず，収書との連動，OPAC はない。目録業務にのみNACSIS-CATを使い，利 用者へはこのデータをもとにカードを打ち出し提 供している。

現在の作業方法が確立したのは1990年 4 月で, 接続当初の1989年 9 月から1990年 3 月までは，手 作業でカードを作成する従来の方法と平行して, 該当書誌がヒットしたもののみ所蔵を登録すると いう，いわば二重の目録作業を行っていた。端末 のオペレーションやMARCによる目録に慣れる ためである。

作業の手順として, 図 2 のとおりいったん画面 コピーを出し,チェック後に登録を行っている。

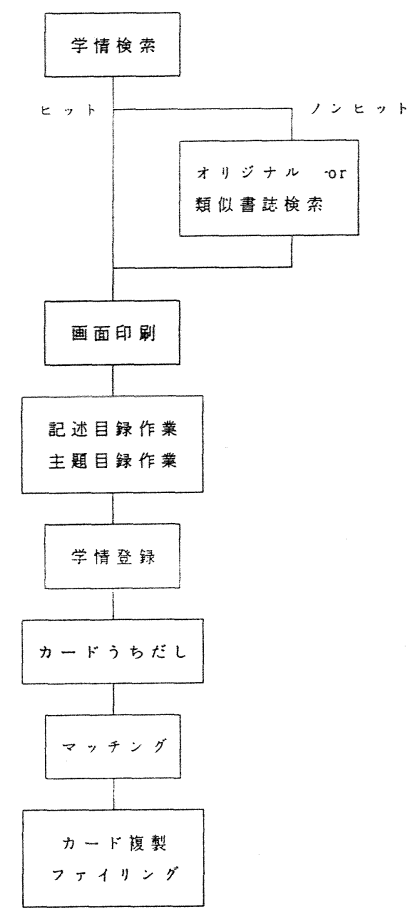

図 2、NACSIS-CATを使った目録作業の流れ

これは, 担当者 2 名がそれぞれの目録作業（記述 及び主題）をシート上で確認しているためである。 また統計をとる際のワークシートとしてむ画面コ ピーを利用している。端末に向かう時間を少なく するという効果すある。なお，書誌はヒットさえ すればたいていスペルミスの修正, 注記の補い程 度で斉むので, 記述のチェックのためだけならす ベてについてアウトプットをだす必要はないだろ う。

主題目録作業は具体的にはMeSHの付与,NLM 分類付与および請求記号決定である。洋書はこの $2 つ の$ 主題情報を含んだLC/MARCからの流用 レコードが多く，そのまま利用できる。翻訳あの の和書む, 同様に原書のレコードを参考にできる。 手作業の時もCIPデータ,NLMの Current catalog を利用してきたが，オンラインアクセスでより簡 単に, 安価にこれらの情報を得られるようになっ たわけである。

作業の能率に大きく影響するものに書誌のヒッ 
表 1. NACSIS-CAT登録件数とその内訳（1989.7-1990.12）

(和書)

\begin{tabular}{|c|c|c|c|c|c|c|c|c|c|c|c|}
\hline & $\mathrm{NC}$ & $(\%)$ & 流用 & (\%) & オリシジル゙ & (\%) & 登録計 & $(\%)$ & 未登録 & (\%) & 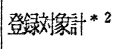 \\
\hline 1989年度 & 430 & $51.8 \%$ & 129 & $15.5 \%$ & 0 & $0.0 \%$ & 559 & $67.3 \%$ & 271 & $32.7 \%$ & 830 \\
\hline 1990年度 & 439 & $66.2 \%$ & 78 & $11.8 \%$ & 146 & $22.0 \%$ & 663 & $100.0 \%$ & 0 & $0.0 \%$ & 663 \\
\hline 合計 & 869 & $58.2 \%$ & 207 & $13.8 \%$ & 146 & $9.8 \%$ & 1,222 & $81.8 \%$ & 271 & $18.2 \%$ & 1,493 \\
\hline
\end{tabular}

（洋書）

\begin{tabular}{c|cccccc|rrrr|r}
\hline & NC & （\%) & 流用 & （\%) & オリジナル & (\%) & 登録計 & (\%) & 未登録 & （\%) & 登録対象計 \\
\hline 1989年度 & 342 & $53.2 \%$ & 264 & $41.1 \%$ & 0 & $0.0 \%$ & 606 & $94.2 \%$ & 37 & $5.8 \%$ & 643 \\
1990年度 & 492 & $60.4 \%$ & 293 & $36.0 \%$ & 30 & $3.7 \%$ & 815 & $100.0 \%$ & 0 & $0.0 \%$ & 815 \\
合計 & 834 & $57.2 \%$ & 557 & $38.2 \%$ & 30 & $2.1 \%$ & 1,421 & $97.5 \%$ & 37 & $2.5 \%$ & 1,458 \\
\hline
\end{tabular}

*1 1989年度はヒットしないあのは登録しなかった。したがってオリジナル入力はない。

*2 登録対象外は数に含んでいない。

ト率がある。表 1 が当センターの登録統計である。 和書, 洋書に差はあるが大半はヒットするという 印象である。NCファイル（総合目録ファイル） の書誌レコードはすでに接続館の手で完成されて おり，これにヒットすれば最す簡単に登録作業が できる。和書, 洋書とも1989年から1990年にかけ てNCヒット率が目に見えて向上している。接続館 が1990年 3 月末で126(うち医学関係図書館43), 1991年 2 月末で150（同47）と確実に増えており， スケールメリットの現われといえよう。

当センターが登録開始にあたって懸念していた のは和書のヒット率である。ひとつは医学関係の 図書館がどのくらい NACSIS-CAT を利用して いるか不明であったし，うひとつは参照MARC のタイムラグの問題がある。一般に医学図書館で 受け入れる図書はほとんどが新刊で, 利用に即し て受入から整理までの時間む短い。当センターの 図書についてMARCによる整理の可能性を調查 した玉井の報告 ${ }^{2)} \mathrm{JAPAN} / \mathrm{MARC}$ のイムラグ の大きさを指摘し，実用には適さないとしている。 （和書）

\begin{tabular}{lcccl}
\hline 対象書誌 & 入力年 & $\mathrm{NC}$ & 流用 & $\mathrm{NC}+$ 流用 \\
\hline $\mathrm{NC}$ 全体 & ～1989年 & 73.2 & 18.6 & 91.8 \\
$\mathrm{NCC}$ 新刊書 & 1986 89年 & - & - & $95.5^{* 1}$ \\
当センター & 1989年度 & 51.8 & 15.5 & $67.3^{* 2}$ \\
当センター & 1990年度 & 66.2 & 11.8 & 78.0 \\
\hline
\end{tabular}

(洋書)

\begin{tabular}{lcccc}
\hline 対象書誌 & 入力年 & NC & 流用 & $\mathrm{NC}+$ 流用 \\
\hline $\mathrm{NC}$ 全体 & ～1989年 & 54.2 & 32.1 & 86.3 \\
$\mathrm{NC}$ 新刊書 & 1986 89年 & - & - & 89.8 \\
当センター & 1989年度 & 53.2 & 41.1 & 94.3 \\
当センター & 1990年度 & 60.4 & 36.0 & 96.4 \\
\hline
\end{tabular}

*1 NACSIS-CAT 稼働の1986年〜調査時点の1989年 出版のNCファイル中の全レコードニカレントに入 カされたと思われるレコード

*2 1989年度は1989.7〜1990.3，1990年度は1990.4〜 1990.12

またもうひとつの参照MARCであるTRC-MARC 
はタイムラグこそ小さいあのの医学専門出版社の 図書については網羅性に不安がある。

利用の結果, 予想より高かったNCのヒット率 のおかげで流用と併せれば実務に差し支えはなかっ た。しかし，NCレコード全体のヒット率と比較 すると，たしかに和書は率が低い（表 2 ）。理由 は前述のとおりだろう。年々上がるNCのヒット 率に期待したい。

今後機械化が拡大し, 収書, ないしは発注段階 で書誌が必要になった場合は当然ヒット率は落ち， NACSIS-CATからの書誌取り込みはあまり期待 できないだろう。しかし目録段階になればかわら ず高率でMARCの提供を受けることができる。

入力に要する時間は, 対象とした書誌によって かなり違う。よってほんの一例として受け取って 頂きたいが，当センターでの実験をむとに推計す ると，事前にある程度入力事項をかためておき検 索加ら登録を一度に流すとすると，1件につき約 4 分から10分かかる。これを長いと感じるか，短 いと感じるかは人それぞれだろう。書誌的には医 学図書館で収集する図書は人文・社会科学分野と 比較すると簡単だが, 当センターは端末のレスポ ンスは遅い。

あちろん，つまずくあのがあるとさらに大幅に 時間をとられる。最も不運なのは「重複書誌」 「重複典拠」を発見，もしくは自ら作ってしまう という事態である。重複レコードは, NACSISCATが，書誌ユーティリティであると同時に総合 目録であるという性格から，厳に禁じられている ことで，これを発見したら責任をもって処理しな ければならない。基本的にはこの目録システムは 図書については，書誌，典拠レコードは誰でも修 正が可能という柔軟なシステムなのだが，その分 参加館の自覚に期待しているともいえる。

ほかに通常の作業で手間がかかるといわれるこ とに典拠作業がある。おむに運用されているのは 著者名典拠だが，NACSIS-CAT が発足した当初
は書誌レコードと典拠レコードのリンクづけが必 須で，その煩雑さのために登録レコードが増えな いといわれた曰く付きの作業である。現在は必須 ではなくなったが, 結局70\%の高率でリンクづけ がされているそうである。”これには自動検索， 新規作成時の標目のはめ込みなど, システムの機 能充実が大きく貢献していると思われる。また外 国人はLCの著者名典拠が参照ファイルとして搭 載されているのでほとんどヒットする。私の実感 であ慣れればそれほど負担とは思えない。当セン ターの運用では，著編者の記述されている範囲は 必須, それ以外（訳者, 監修等) は準必須として ほとんどの典拠リンクを行っている。

問題となるのは同定が難しい場合だが，先にも 述べたように幸い医学図書館では受け入れる図書 は新刊がほとんどで, 個人名, 団体名, 会議名と あ調查がしやすい。

むしろ典拠コントロールという作業自体が日本 の図書館にとってあまり経験のなかったことで， そのために典拠作業への負担感が大きかったのか もしれない。当センターも手作業時代は典拠ファ イルを作っておらず，厳密なコントロールは行っ ていなかった。そのための戸惑いはあった。

当センターでは NACSIS-CAT への所蔵登録 と同時に学内にレコードをダウンロードしている。 学内の他センターには洋書のレコードをOPACに 提供しているところもあるが，当センターはカー ド打ち出しにのみ使っている。カード打ち出しの プログラムは三田情報センターのスタッフがオリ ジナルで開発したものである。打ち出しの際はま ず当センターの NACSIS-CAT 用端末を三田の 大型計算機に接続し直してバッチジョブを流す。 プリントアウトは, 設備の関係で三田情報センター に依頼している。ここのスタッフが三田の計算セ ンター内で作業し, 塾内便とよばれる学内定期便 でカードを送ってくれる。カードの仕様はできる 限り従来の，オリジナルで作っていたすのと整合 
性を保つようにしてあるが，それであいくらかの 手直しが必要になる。例えば，NACSIS-CAT レ コードはほとんど FULL MARC を流用するた め概して従来のローカルなカード目録より羊詳細 である。記述はそのままとしてす副出指示の件数 を減らしたり，標目をローカルな形に直す。印刷 カードを使う場合と同じ要領である。また NAC SIS-CAT のレコードには漢字の読みがカナしか 入っていないので, 副出指示のためにローマ字変 換のモジュールを通している。しかし外来語は原 綴とするといった細かなローカルルールまでは機 械で処理できない。さらに階層のある書誌は思い どおりの形での出力は技術的に難しく，最初から 別の方法でオリジナルカードを作成してしまって いる。

目録システムは基本的には機械可読形態を原則 としているので, やはり印刷媒体に出力するとき には余分な労力が必要になるということだろう。

\section{IV. 目録情報の特徵}

NACSIS-CAT を利用すること，つまりオンラ イン共同目録に参加するあるいは総合目録データ ベースを構築するということで，作業の手順だけ でなく目録情報の中味む大きく変わる。

既存のMARCから簡単に詳細な目録情報を得 られる。一方, 従来ひとつの図書館の中だけで発 生から利用まで終始していた目録情報が，全国さ らには国際的に流通することになる。オリジナル で新規作成したり修正を加える場合は一定の質を 要求される。当然ローカルルールは馴染まない。 入力基準はNCR 87 , AACR 2 という2大メジャ 一規則を基本としているが，やはり相違がある。 また，機械可読デー夕，総合目録データベースの 特徴としてゆれを嫌う。既存の目録規則の中には 選択の余地を残した別法，任意規定があるが， NACSIS-CAT ではこれらの採用の可否を綿密に
決めている。ただし，検討中の事項も多い。つま り結局はこれらの新しい規則に習熟する必要があ る。

NACSIS-CAT のレコードの最も大きな特徵は 書誌作成単位の基準之階層の表現である。以下の 基準を書誌作成単位の根拠としている。「書誌単 位は, 固有の標題, 著者等によって書誌的に他と

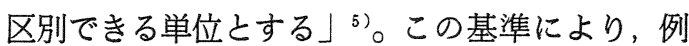
えば「現代皮膚科学大系」のいわば目次情報のよ うな「検査・実験法, 治療, 感染症, 水疮・膿疮 性疾患, 薬疹・中毒疹, 膠原病, 代謝異常」6) 標題とみなされ，これをタイトルとした書誌が作 成される。

階層を持つもの（いわゆるシリーズやセットも の）は最上位の書誌と最下位の書誌についてレコー ドを作成し，それぞれリンクづけすることで表現 する。中位の書誌については最下位のレコード中 に記述するにとどめる。

これらの基準は特有のものであるため，参照 MARCとはくい違うことがある。図 3 はLC/ MARCとNCレコードの相違の例である。書誌作 成者の判断の違いから，しばしば重複書誌作成の 原因となる。目録情報の本質論はとあかく，現実 にはこの基準をのみこまなければならない。

当センターでは NACSIS-CAT の登録を始め る準備として，接続前に講習会に 1 名が参加。 （もう1名はおって参加。）担当 2 名がひととお り NACSIS-CAT のマニュアルを通読し, ローカ ルルールの洗い出しや, 内部の申し合わせなど行っ た。しかし，オペレーションについては 1 力月ほ よ゙で慣れるが，入力基準についてはどうしても多 様なケースそれぞれに遭遇しないと覚えない。そ のため当初は暧昧な点が多く, 入力途中でマニュ アルをひっくり返す，問い合わせをするといった 場面む少なくなかった。特に初期は，重複書誌を 作成して先発の図書館に迷惑をかけたこともある。 言い訳をすれば，従来当センターでは目録は書 
L C

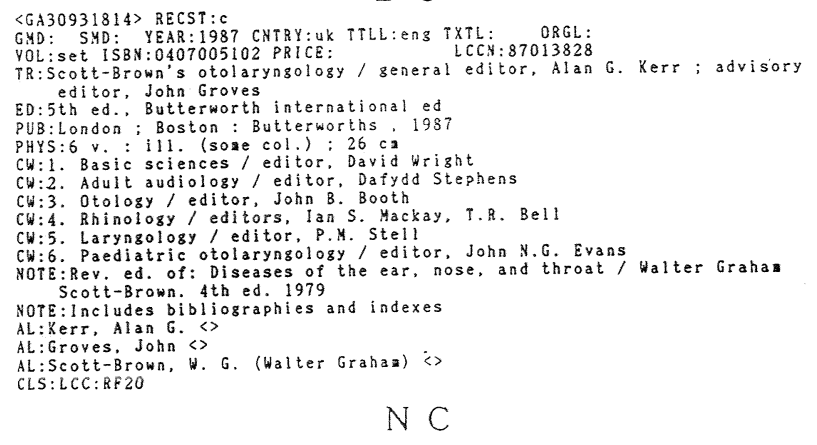

\section{親書誌}

¿BA01310200> CRTDT: 19880119 RNADT: 19880119 TXTL:ENG ORGL

YOL: ISBN:0407005102 PRICE:

$T R: S \cot t-B$ rown's otolaryngology

TR:Scott -8 ro
ED $: 5$ th ed

PUB:London: Butterworths

子 1 子 2 子 3

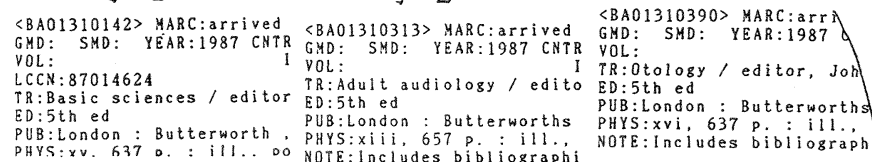

$$
\text { 子 } 4 \text { 子 } 5 \text { 子 } 6
$$

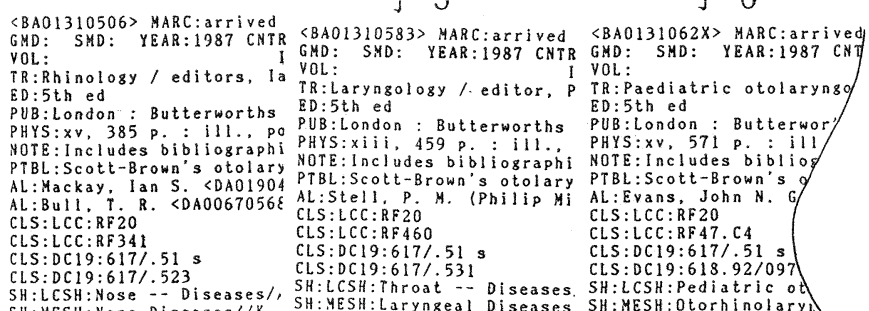

図 3. 書誌作成単位亡階層表現の相違

同一の 6 冊セットの書誌。上がLC/MARC,下がNACSIS-CATのNCファイル中のレコード

親が「集合書誌単位」，子がそれにリンクづけされている「単行書誌単位」

誌的事項の記録という面よりむ, ファインディン グリストとしての機能を重視しており,カード時 代比較的簡単な目録しかとっていなかった。この ため目録情報についてかなり勉強をすることになっ た。

\section{V. 今後の展開}

学術情報センターの利用の手引 そ) にああると おり，目録システムはローカルな機械化を支援す るシステムとしてあ位置づけられる。

冒頭でふれたように，当センターでも学内の他
センターと共同で全業務の機械化を控えている。 準備中の新しいシステムは外部書誌ユーティリティ としてNACSIS-CATを利用する。NACSIS-CAT からダウンロードでローカルファイルに書誌を取 り込み, アップロードで NACSIS-CAT へ登録を 行うというあのである。この類のシステムは国立 大学図書館を中心にすでに数多く稼働している。 また立ち上げ時のデータとしてこれまでに登録し たレコードを個別版MTで供給してもらい，セッ トアップする。ちなみにこのMT作成は無料であ る。学内の計算機にダウンロードしたデータを使 うことも考えられたが, 新システムを想定してい 
表 3. 参照MARC収納状況

(1991年 3 月 7 日現在)

L C 図書書誌 (V19\#07まで)

(1968.01-1991.02)

雑誌書誌（V19\#01まで）

(1973.01-1991.01)

著者名典拠（V14井07まで）

(1977.01-1991.02)

統一書名典拠（V14\#07まで）

(1977.01-1991.02)

J P 図書書誌 (V91 \#09まで)

(1969.01-1991.03)

雑誌書誌（V90 01まで）

(1988 -1990)

著者名典拠（センター作成）

UK図書書誌（N2128まで）

(1950.01-1991.02)

T R C 図書書誌（肃91008まで）

(1985.04-1991.02)

G P O 図書書誌（V15\#01まで）

(1976.01-1990.01)

ないデータだったので，改めて個別版を取り寄せ ることになった。当センターでは新システム稼衝 時に，機械可読データとして，当センター内だけ で収書業務のため1980年から蓄えてきた簡易書誌 レコード約 30,000 件とあわせて, NACSISCAT に登録したいわば完全書誌レコード約 4,000 件を備えることができる。

あちろんNACSIS-CATを使った遡及入力む可 能である。参照MARCは表 3 のとおり，かなり 古い年代までむカバーしている。学術情報センター 側でも遡及入力の便を計るため，東京大学図書館 との共同事業で, 同図書館の蔵書のデー夕をカー ドから起こして参照レコードとして提供している。 さらに接続館独自でもNACSIS-CATを使った遡 及入力が行なわれ，かなりの件数が総合目録ファ イルに登録されている。医学関係の例む 2 館ほよ゙ 聞いている。当センターであ新システムのもとで NACSIS-CATを使った遡及入力を計画中である。

\section{VI. おわりに}

以上学術情報センター目録システムを使った目 録作業について述べてきた。NACSIS-CAT導入は， 目録業務にとって大きな变化で, 移行の苦労ああっ た。しかし機械化はすでに避けられない道である。 当センターであ全業務機械化へのワンステップと して学術情報センターとの接続があった。

NACSIS-CATは, 日本で唯一の大規模書誌ユティリティで，最も身近な目録システムになりつ つある。先に接続した一私立大学医学図書館とし ては，仲間を増やしたいという希望を持つ。この 報告が実務者の不安を取り除くと同時に共通の舞 台に立っきっかけになれば幸いである。

この報告は1991年 1 月30日に慶應義塾大学医学 部北里講堂にて開催されたセミナー「学術情報セ ンターに期待する」での発表をもとに加筆したも のである。

発表, 執筆にあたって快く資料を提供してくだ さった学術情報センターの小西和信氏に深謝いた します。

\section{引用文献}

1) KUCC : Keio University Computer Center. No. 15. p. 48(1990) より転載。

2) 玉井裕子 医学書とJapan MARC. 明日の医学 図書館へ向かって: 第12回医学図書館セミナ一論 文集. 日本医学図書館協会, 1985

3) NC全体, NC新刊書のヒット率は以下の調查研究 による. 石井啓豊 目録所在データベースの統計 的分析分類と索引とデータベース : 山田常雄氏追 悼論集, 山田常雄氏追悼論集刊行委員会, 1990.

4）永田治樹 目録・所在情報システム：その展開と新 たな課題. 情報科学と技術. 40（3）：175-82.

5 ）学術情報センター編. 目録システム利用マニュア ル.データベース編. 改訂版（目録情報の基準 第2 版). 学術情報センター, 1990.

6 ）久木田淳他編 現代皮膚科学大系. 年刊版 ' $90-\mathrm{B}$, 1990.

7 ）学術情報センター編. 目録・所在情報システム利 用の手引. 改訂版. 学術情報センター, 1990. 